\title{
A SOMBRA DE UM LIVRO AUSENTE: O SÍMBOLO DA MORTE E DA DECADÊNCIA EM DOIS MOMENTOS DA INTRODUÇÃO À HISTÓRIA DA SOCIEDADE PATRIARCAL NO BRASIL, DE GILBERTO FREYRE
}

\section{ARTIGO ORIGINAL}

RIBEIRO, René Salmito ${ }^{1}$

NASCIMENTO, Expedito Tomaz do ${ }^{2}$

RIBEIRO, René Salmito. NASCIMENTO, Expedito Tomaz do. A sombra de um livro ausente: o símbolo da morte e da decadência em dois momentos da Introdução À História Da Sociedade Patriarcal No Brasil, de Gilberto Freyre. Revista Científica Multidisciplinar Núcleo do Conhecimento. Ano 05, Ed. 11, Vol. 08, pp. 115130. Novembro de 2020. ISSN: 2448-0959, Link de acesso:https://www.nucleodoconhecimento.com.br/sem-categoria/a-sombra

\section{RESUMO}

Considerando-se que a trilogia conhecida de Gilberto Freyre Introdução à história da patriarcal no Brasil - composto por Casa-grande \& senzala, Sobrados e mucambos e Ordem e progresso - parece um todo coeso, a não publicação do quarto ensaio, que tornaria a obra uma tetralogia, Jazigos e covas rasas (que versaria sobre os rituais fúnebres brasileiros de meados do século XIX até o começo do século $X X$, tendo como pano de fundo o desenvolvimento do positivismo e do republicanismo no Brasil, assim como o último publicado da Introdução, e aproveitaria o tema da morte como metáfora para a decadência do patriarcado no Brasil), é inevitável que se façam duas perguntas,

\footnotetext{
${ }^{1}$ Mestre em Ciências da Educação (Universidad Del Sol), Especialista em Gestão e Coordenação Escolar (Universidade Vale do Acaraú), Especialista em Literatura Brasileira (Universidade do Estado do Ceará), graduado em Letras/Português (Universidade de Fortaleza).

${ }^{2}$ Mestre em Ciências da Educação.
} 
que no fim podem se reduzir a uma só: como essa obra ausente, que Freyre afirma ter escrito, mas perdido, teria mudado a percepção das obras anteriores, e em segundo lugar se, apesar de perdido o original, suas ideias não estariam imbricadas nas obras anteriores, se perceber a insistência com a qual o título não publicado é citado nas introduções a Sobrados e mucambos e Ordem e progresso. Pensando sobretudo o prefácio à segunda edição do segundo livro da trilogia original e a transição que se dá entre Casa-grande \& senzala e Sobrados e mucambos (os dois momentos de que fala o título desta análise), busca-se aqui mostrar como a metáfora morte/decadência já se encontra na trilogia original e que consequências pode esta mesma metáfora ter numa releitura da obra de Gilberto Freyre, localizando-a como um libelo em defesa de um modo de sociedade que está se extinguindo e do qual o autor se mostra um beneficiário e um saudosista.

Palavras-chave: Decadência do patriarcado, Brasil-colônia, Brasil-império, sociologia do Brasil.

\section{INTRODUÇÃO}

Na introdução à segunda edição de Sobrados \& mucambos, cuja edição anterior data de 1936, Gilberto Freyre descreve brevemente o projeto de encerrar a série de livros Introdução à história da sociedade patriarcal no Brasil, a princípio uma trilogia, com um quarto livro. O primeiro, o célebre Casa-grande \& senzala, dá conta propriamente da construção do patriarcado rural a partir, sobretudo, dos engenhos de cana de açúcar do nordeste, cujo auge se dá no século XVII, e faz a mais importante análise, na sua época, da participação do negro na formação da sociedade brasileira que não se baseava em pressupostos eugênicos de inferioridade de raça, como pressupunham estudiosos importantes como Oliveira Viana.

O segundo, o já referido Sobrados \& mucambos, fala de como o Brasil, a partir de três fatos históricos decisivos (a saber, a exploração do ouro em Minas Gerais, que no século XVIII deslocaria o eixo econômico da colônia da agricultura para a mineração, sendo o primeiro grande golpe sofrido pelos engenhos de cana-de-açúcar, a vinda da família real ao Brasil, em 1808, e a declaração da Independência de 1822), começa a 
se urbanizar, e como essa urbanização, aos poucos, inicia um conflito entre o espaço doméstico e a rua, conflito que redundará no gradual questionamento ao patriarcalismo.

O terceiro, Ordem e progresso, fala da evolução do discurso positivista no Brasil, sua influência nas forças armadas e como as mesmas eram uma das frentes democráticas mais importantes do país, não só por abrigar também o negro e o mulato, mas antes de mais nada porque ali os mesmos teriam uma possibilidade de ascensão social que poucos setores da sociedade Ihes ofereciam. O quarto livro, que transformaria a trilogia em tetralogia, também tinha um título dicotômico, e falaria de rituais fúnebres. Como nos dois primeiros, o título dava a ideia de dualidade entre a vida dos mais ricos e dos mais pobres.

Jazigos e covas rasas - o título com que deverá aparecer o trabalho de conclusão de nossos estudos - cobrirá o mais possível, como estudo de ritos patriarcais de sepultamento e da influência dos mortos sobre vivos, aquelas várias fases de desenvolvimento e de desintegração desintegração na qual ainda se encontra a sociedade brasileira - do patriarcado, ou da família tutelar, entre nós. Patriarcado a princípio quase exclusivamente rural e até feudal, ou parafeudal; depois, menos rural que urbano. (FREYRE, 2002, p. 674)

O quarto livro acabou nunca sendo escrito. A Introdução permaneceu uma trilogia, mas a presença do tema da morte permanece como uma metáfora potente que dá conta da transição operada entre os dois primeiros livros: a morte não é apenas a morte física, naturalmente, mas dá conta da decadência de todo um mundo, um mundo do qual Gilberto Freyre se sentia e se confessava herdeiro e cuja memória pretendia compreender e conservar.

\section{A OBRA DE GILBERTO FREYRE: PATRIARDO REVISATO}

Em resenha sobre Casa-Grande \& Senzala: o livro que dá razão ao Brasil mestiço e pleno de contradições, ensaio de Mario Helio Gomes de Lima sobre a obra do sociólogo pernambucano, Amurabi Oliveira divide a recepção da obra de Gilberto Freyre em três momentos decisivos: 
(...) o primeiro iria de sua publicação até a metade dos anos de 1960, quando haveria mais avaliações positivas do que negativas sobre o livro, ainda que houvesse ataques por parte dos conservadores no que diz respeito ao uso da linguagem coloquial, à crítica aos jesuítas e à apologia à cultura afro-brasileira; o segundo iria da metade dos anos de 1960 até os anos de 1980, período em que o trabalho é combatido por sua suposta falta de cientificidade e pela interpretação assumida sobre a sociedade brasileira, porém Helio ressalta que muitas críticas eram realizadas sem que o trabalho fosse lido; e, por fim, terceiro momento se inicia nos anos de 1990 e se acelera com as comemorações do centenário de seu nascimento nos anos 2000, quando surgem novos trabalhos que visam a aprofundar a análise de sua obra. Nesse ponto, Helio nos traz uma seleção de alguns trabalhos produzidos nesse período que ele considera emblemáticos, indicando ainda outras fontes complementares para uma melhor compreensão de Casa-Grande \& Senzala. (OLIVEIRA, 2015, p. 455)

O primeiro momento é aquele que mais facilmente se compreende pelo contexto, apesar da distância temporal, dada a relevância e a revolução que a proposta da obra apresentará no contexto intelectual brasileiro, apesar de tantas décadas já passadas, ou justamente porque o distanciamento muitas vezes ajuda a se ver mais claramente. A Introdução, iniciada com Casa-grande \& senzala, surge basicamente com três propostas revolucionárias para a sociologia. A primeira diz respeito ao aspecto formal. Freyre se afasta dos métodos tradicionais utilizados até o momento, afasta-se de questões estatísticas, torna a pesquisa mais qualitativa do que quantitativa, ao mesmo tempo em que elege documentos até então circunstanciais, como jornais antigos, anúncios, canções e outros elementos como fonte.

Freyre opera, sobretudo, intenso investimento estilístico: perceba-se a extrema familiaridade passada pelo texto, sobretudo o primeiro da trilogia, o que torna a obra mais acessível, mesmo para aquele que não se dedica profissionalmente à sociologia ou à antropologia. Tratam-se de livros que podem ser lidos por pura fruição estética, apesar de, em muitos pontos, essa familiaridade descambar para a linguagem mais coloquial, utilizando deformações de palavras, para falar como o próprio povo, e sem se furtar à referência mesmo ao palavrão direto, quando isso parece ao autor necessário para a elucidação de algum contexto. Simplicidade textual aparente, diz o próprio autor (ressaltando na explicação os aspectos mais familiares), falando de influências diretas que assimilou durante a infância, e colocando na construção da 
linguagem um reflexo do amalgama étnico que ele demonstra na construção do brasileiro.

A sociologia, enfim, abandona o tratado e abraça a forma mais livre do ensaio, o qual, no dizer de Adorno, deixa a pretensão da verdade universal e absoluta para dar espaço às paixões do seu autor. Ou nas palavras do próprio sociólogo pernambucano ao explicar a abertura interpretativa e relativa falta de conclusão do seu texto, com destaque para como essa mesma liberdade se adequa não só a falar de aspectos humanos em geral, mas também especificamente os que dizem respeito à formação do brasileiro:

A quase-ausência de conclusões, a pobreza de afirmações, não significa, porém, repúdio de responsabilidade intelectual pelo que possa haver de pouco ortodoxo nestas páginas. De contrário ao estabelecido, ao aceito, ao consagrado. Porque essa qualidade revolucionária vem da própria evidência do material reunido e aqui revelado e interpretado dentro da maior objetividade possível, de método e de técnica. E tempo de procurarmos ver na formação brasileira a série de desajustamentos profundos, ao lado dos ajustamentos e dos equilíbrios. E de vê-los em conjunto, desembaraçando-se de pontos de vista estreitos e de ânsias de conclusão interessada. Do estreito ponto de vista econômico, ora tão em moda, como do estreito ponto de vista político, até pouco tempo quase o exclusivo. O humano só pode ser compreendido pelo humano até onde pode ser compreendido; e compreensão importa em maior ou menor sacrifício da objetividade à subjetividade. Pois tratando-se de passado humano, há que deixar-se espaço para a dúvida e até para o mistério: a história de uma instituição, quando feita ou tentada sob critério sociológico que se alongue em psicológico está sempre nos levando a zonas de mistério, onde seria ridículo nos declararmos satisfeitos com interpretações marxistas ou explicações behavioristas ou paretistas; com puras descrições semelhantes às das história natural de comunidades botânicas ou animais. (FREYRE, 2002, p. 667-668)

Gilberto Freyre adotará essa liberdade ao ponto mesmo de dizer que já não é propriamente um sociólogo, ou unicamente um sociólogo. Porque, do seu ponto de vista, a questão mais especificamente estatística que muitas vezes norteava os trabalhos na área deixavam de lado justamente o material humano, que vai ser o seu foco principal. 
A segunda ruptura, relativamente visível no trecho acima, diz respeito à utilização de análises que abordam questões especificamente econômicas, tendência muito forte no materialismo histórico. Com a diferença radical de que Freyre não verá na economia apenas números, mera circulação de mercadorias ou relações de trabalho. Freyre parte daquilo que contemporaneamente parece óbvio: a formação brasileira se baseia na exploração de recursos naturais da terra selvagem, em primeiro lugar, e em segundo lugar do início da monocultura, ou seja, o ciclo da cana-de-açúcar iniciado no século XVII, e consequentemente numa estrutura de trabalho baseada na escravidão, resumidamente em aspectos econômicos que é preciso conhecer profundamente, mas no caso de Gilberto Freyre para extrair desses dados uma base para a compreensão do humano, bem mais do que do puramente econômico: Freyre vai se interessar pelas relações sociais que surgem a partir e ao redor das questões econômicas mais evidentes, chegando mesmo a abordar diretamente aspectos mais subjetivos, como a construção dos afetos dentro desse universo.

A terceira contribuição, talvez a mais revolucionária, de Gilberto Freyre na construção de uma nova sociologia foi o que posteriormente se tornou uma espécie de faca de dois gumes de sua teoria. Uma valorização do negro e da miscigenação na sociedade brasileira0 como nunca tinha sido feita antes. É certo que o abolicionismo, do século anterior, fomentará um discurso pela igualdade racial que redundava na igualdade de direitos, e que o próprio fenômeno da miscigenação era visto com uma condescendência que não havia em outras colônias, mormente as colônias inglesas - o que Freyre explica a partir de uma maior plasticidade do português, mesmo em comparação com seus vizinhos espanhóis, pelo fato de serem os próprios portugueses um povo bastante miscigenado.

A importância dessa defesa reside em quanto foi mal visto o negro na sociedade brasileira mesmo após a abolição da escravatura, ou mesmo em decorrência de um profundo ressentimento por parte dos latifundiários escravocratas, que se sentiram traídos com a aprovação da lei. $O$ fato é que um discurso de base eugênica seduz profundamente boa parte da intelectualidade nacional, que colocava, a partir de critérios hoje cientificamente questionáveis, a presença do negro e a mestiçagem como elementos de inferioridade nacional, e depositavam esperanças na 
possibilidade de um gradual branqueamento étnico do Brasil, que acabaria tendo como consequência um gradual branqueamento da sociedade brasileira.

Para Gilberto Freyre, o argumento não se sustenta pelo fato de a questão étnica ser necessariamente menos importante do que as questões sociais e sociológicas propriamente ditas. A construção da sociedade brasileira se dá, para Freyre, em questões que se baseiam bem mais na estruturação da economia e, sobretudo, em como a família patriarcal brasileira surge em torno dessas bases econômicas.

A formação patriarcal do Brasil explica-se, tanto nas suas virtudes como nos seus defeitos, menos em termos de "raça" e de "religião" do que em termos econômicos, de experiência de cultura e de organização da família, que foi aqui a unidade colonizadora. Economia e organização social que às vezes contrariaram não só a moral sexual católica como as tendências semitas do português aventureiro para a mercancia e o tráfico. (...) uma raça não se transporta de um continente a outro, seria preciso que se transportasse com ela o meio físico. (FREYRE, 2002, p. 129)

O ideal da eugenia ganhava adeptos entre a intelectualidade e boa parte da sociedade científica em todas as partes do mundo, entre o fim do século XIX e o começo do século XX. O termo eugenia foi criado por Francis Galton, primo de Charles Darwin, em cujas teorias parece ter se influenciado, embora de maneira deturpada: Darwin acreditava numa seleção natural que culminaria na sobrevivência dos mais adaptados, enquanto Galton acreditava que se podia favorecer um melhoramento genético - mesmo se tratando da raça humana. Logicamente, quando se fala em melhoramento também se fala da eliminação de características indesejáveis, para situá-las, dentro de uma determinada espécie, é preciso que se elejam quais são os portadores dessas mesmas características, os quais, por serem portadores, seriam inferiores aos demais.

Mas, academicamente falando, e para que se possa chegar a um resumo do movimento e das suas consequências na sociologia e antropologia nacionais, vale concentrar as atenções na obra de Raimundo Nina Rodrigues. Nina Rodrigues, cuja obra é anterior à de Kehl, baseava sua obra numa catalogação dos tipos brasileiros e do que ele considerava suas principais características. Associando vícios e crimes 
com as raças, não atentando prioritariamente para fatores econômicos e sociais ao redor, mas antes tornando esses fatores mais consequência do que causa, Nina Rodrigues parte do pressuposto de que as qualidades raciais dependem da pureza dos indivíduos, e que a mestiçagem, o grande ponto de origem étnica do Brasil, seria potencialmente um mal. Para Nina Rodrigues não haveria propriamente uma raça humana única, mas várias, as quais poderiam ser postas de forma hierárquica de acordo com sua superioridade ou inferioridade em relação umas às outras, e que os cruzamentos indiscriminados, que o autor descreve de forma animalesca, poderiam resultar potencialmente em degeneração da espécie ou pelo menos da sociedade que comportasse essas uniões. Grosso modo, cada raça, para Nina Rodrigues, seria dotada de dons específicos e de uma profunda incapacidade de adaptação para os dons de outras raças: a civilização seria o grande dom e destino das raças brancas, no que não podem ser seguidos por indígenas nem por negros, os quais seriam, por natureza, selvagens ou presos a um nível de sociabilidade entre totêmico e fetichista.

Grande impacto teve sobre essas ideias a obra revolucionária de Gilberto Freyre. Embora sociólogo e antropólogo, sua produção, que ao longo de sua vida vai se debruçar sobre os mais variados assuntos, interessa tão fortemente à cultura brasileira que chegou mesmo a ser um fator decisivo na renovação do modernismo. A Segunda Fase Modernista desenvolveu no Brasil uma revalorização das tradições regionais, sobretudo através de Gilberto Freyre, sociólogo recém-chegado dos Estados Unidos, onde estivera a estudos. Em 1924, cria-se o Centro Regionalista do Nordeste e, em 1926, realiza-se o Primeiro Congresso Brasileiro de Regionalismo. A preocupação com a revalorização do Nordeste deve-se em parte ao deslocamento do eixo econômico e cultural para o Sul, quando a indústria açucareira começa a decair. Por outro lado, o capitalismo sem vínculos com a região contribuía para a descaracterização cultural do Nordeste, cuja economia tinha bases patriarcais e paternalistas.

Freyre considera, como nunca antes, os fatores econômicos na estruturação da sociedade brasileira. Ainda assim, não se pode filiar seus estudos propriamente ao materialismo histórico, sobretudo o mais propriamente marxista. Freyre admite certa influência desse veio, mas se diz cauteloso na sua aplicação: para ele, o materialismo 
histórico, ao partir da economia e quase necessariamente voltar a ela, acaba por ignorar aspectos importantes na formação da sociedade, os mais propriamente culturais, e que dão ao estudo uma natureza mais palpável e menos árida. A economia e suas necessidades são um ponto de partida da obra de Gilberto Freyre, mas não um ponto de chegada ou mesmo de retorno.

Os negros, os índios e os mestiços não traziam para o Brasil, por si mesmos, nenhum tipo de degenerescência, mas teriam sido, antes, as relações sociais, derivadas das necessidades econômicas, a origem de boa parte dos males sociais que persistiam mesmo depois da abolição da escravatura e da proclamação da república. Formarase uma imagem sobretudo do negro que se embasara em preconceitos derivados da colonização: que a sífilis teria se alastrado por origem ameríndia e influência africana, quando a origem da doença é mais provavelmente eurasiática e se deve mais provavelmente, portanto, à chegada do colonizador português (FREYRE, 2002), que os negros teriam desenvolvido toda sorte de magias e feitiços erótico-sexuais, quando a maioria desses feitiços era ainda de origem portuguesa (FREYRE, 2002), que as negras africanas seriam libidinosas por natureza e seriam, depois das índias, as grandes tentadoras dos colonizadores brancos, fato negado por muitos viajantes, que encontravam mesmo entre as negras exemplos extremos de recato (FREYRE, 2002). Ao lado dessas teses que dão conta de hábitos domésticos, o preconceito generalizado de que, dadas as condições intelectuais inferiores, os negros seriam destinados necessariamente a trabalhos que se baseavam em força bruta, quando na verdade boa parte da especialização do trabalho em terras brasileiras se deve à experiência técnica dos africanos em sua própria terra de origem. Quanto à questão diretamente sexual, a promiscuidade atribuída aos negros teria duas origens bem distintas: a imensa erotização dos senhores ociosos e as relações entre vencedores e vencidos que nascem necessariamente pela força da colonização e da escravidão.

O negro, na visão de Gilberto Freyre, é um elemento plástico que traz suas próprias contribuições culturais e faz, ele mesmo, com que as outras contribuições dos demais povos se aprofundem e se adaptem: adota a religião dos conquistadores e se torna seu difusor, incrementa a culinária local com contribuições próprias, mas aperfeiçoa os pratos de outras culturas, adota a língua portuguesa, mas, junto com o indígena, 
faz com que essa língua se amanse e receba várias contribuições nativas que tornam o som do português falado no Brasil mais cantante e agradável, menos árido do que aquele que vem de Portugal. Assimilado mesmo à custa de extrema violência, entra para a casa-grande, para a vida social e para os afetos: pode ser tornado da família o mestiço mesmo muitas vezes será meio branco por causa do sangue do senhor de engenho, que tolera a bastardia melhor do que nas colônias anglo-saxônicas ou mesmo espanholas, e acaba por aceita-la. Exemplos pontuais (cuja importância e influência Freyre talvez exagere) localizam negros, índios e mestiços como sacerdotes, mestres alfabetizadores e membros importantes da sociedade. (No caso específico do sacerdócio, sabe-se que, com todas as suas contradições internas, a igreja católica podia ser bastante condescendente neste ponto.) Freyre quer ressaltar que, em comparação com modos de colonização que evitavam e/ou condenavam francamente a miscigenação, havia entre nós maior possibilidade de democratização racial e de ascensão social pelo elemento não-branco (o que não é o mesmo de dizer que não havia racismo e preconceito, os quais o autor debela na raiz, ainda que não na estrutura).

Ainda assim, considerando as fases de recepção que acompanham a obra de Freyre ao longo do tempo, não se pode esquecer que, apesar desses aspectos revolucionários, o próprio Gilberto Freyre se considerava um conservador - o que fica bastante claro quando se percebe o saudosismo que perpassa sua obra: Freyre é confessadamente um beneficiário daquela estrutura decadente, e critica, ora com certa sutileza, ora de modo direto, todos os avanços do progresso que parecem ameaçar o seu mundo. Freyre não chega propriamente a negar o processo de violência em que o mesmo se baseia, mas abre a possibilidade de um princípio de democratização racial que de certo modo ameniza a violência a partir da qual o mesmo se constrói.

Freyre, após defender ferrenhamente a importância do elemento negro na construção do Brasil, acredita e defende a construção de uma democracia racial, e que esse modo de democracia baseado na miscigenação, cuja efetiva existência mais de uma vez foi alvo de severas críticas, seria mesmo melhor do que a democracia tradicional, cujo discurso se fortalecia no ocidente. 
A ideia de democracia social e racial, herdeira de antigas tradições comunitárias, na qual a convivência não exclui a hierarquia, é apresentada por Gilberto Freyre como uma criação (ibérica, particularmente luso-brasileira) mais rica e mais legítima do que a moderna democracia política. Não só a democracia política e, por consequência, o sufrágio universal não seduziam Gilberto Freyre. Outras instâncias culturais identificadas com a racionalidade burguesa também o incomodavam, entre elas o alfabetismo, que - argumenta em texto de 1923, acerca da obra de Agripino Grieco - levaria à "mediania" e à homogeneização. (SCHNEIDER, 2012, p. 79)

A dificuldade de encontrar o tom preciso, a intenção de Gilberto Freyre, está em como boa parte de suas declarações se dão por assim dizer no calor da hora, a partir inclusive de artigos publicados em jornais. Não se pode, isso é certo, construir uma caça às bruxas, esquecer o legado da obra de Gilberto Freyre ou até mesmo culpabilizá-la. Assim como não se pode também, por outro lado, esquecer ou deixar de lado suas inúmeras contradições. É preciso compreender a obra em si mesma. E curiosamente um dos marcos que melhor pode dar uma chave interpretativa para isso é, justamente, o livro que misteriosamente se perdeu.

\section{MORTE E DECADÊNCIA: O LIVRO DESCONHECIDO}

Ainda que não tenha sido propriamente escrito, pode se dizer que o livro se encontra presente, de maneira quase obsessiva no extenso Prefácio citado no início, escrito, e provavelmente revisado e reescrito inúmeras vezes, segundo nota final do autor, entre maio de 1949 e março de 1961. A princípio, portanto, pouco se poderia dizer desse livro, não fossem os comentários antecipados do autor, o tom em que se expressam e o modo como esses trechos dialogam de forma às vezes bastante forte com os volumes efetivamente publicados da sequência. Freyre parece amargurado, como não parece ocorrer em outros trechos da obra em relação a outros assuntos. A questão não é o fato em si de ele estar falando do fenômeno da morte, mas o que essa morte significa em aspectos simbólicos. Não era da morte como devir que ele parece falar, mas da morte como fato consumado, tão consumado que o mote são as construções e os rituais que a rodeiam. Mas antes de tudo o abandono por que passam esses vestígios do passado, tanto no que diz respeito às antigas residências para os vivos como nas que se ergueram para os mortos. 
Essa decadência também se dará com a residência dos mortos assim como com a residência dos vivos. As próprias residências dos vivos tendo perdido seus donos originais e sua original respeitabilidade. Uma outra guerra além daquela declarada em Sobrados e mucambos foi declarada ao patriarcalismo. Nesse primeiro momento, quando o Brasil começa a se urbanizar, a rua entra em guerra com a casa: é na rua que devem se construir as relações sociais, e não meramente sob o jugo do patriarcado mais bruto. Esse se defende em construções o mais sólidas possível, dando o mínimo espaço para respiração às crianças e sobretudo às mulheres (são as mulheres sobretudo o que mais se guarda nessas construções), mas com o tempo as janelas foram se abrindo, o vidro substituiu muitas vezes as persianas, os rituais da rua começaram a vencer as barreiras da casa, mas essa não foi a maior das derrotas sofridas pelo antigo patriarcado: com a gradual queda das antigas famílias, são as próprias casas que passam a outros donos ou a outras finalidades, abandonadas que foram pelas antigas famílias. Degradam-se em funções menos nobres e mais gerais. Ou são simplesmente abandonadas. O mesmo destino que acompanha as antigas lápides.

O túmulo monumental ou jazigo chamado perpétuo ou a simples cova marcada com uma cruz de madeira - prolongamento das casas-grandes, depois dos sobrados, das casas térreas, dos mucambos, hoje das últimas mansões ou casas puramente burguesas e do número casario pequeno-burguês, camponês, pastoril e proletário - é, como a própria casa, uma expressão ecológica de ocupação ou domínio do espaço pelo homem. O homem morto ainda é, de certo modo, homem social. E, no caso de jazigo ou de monumento, o morto se torna expressão ou ostentação de poder, de prestígio, de riqueza dos sobreviventes, dos descendentes, dos parentes, dos filhos, da família. O túmulo patriarcal, o jazigo chamado perpétuo, ou de família, o que mais exprime é o esforço, às vezes pungente, de vencer o indivíduo a própria dissolução integrando-se na família, que se presume eterna através de filhos, netos, descendentes, pessoas do mesmo nome. E sob esse ponto de vista, o túmulo patriarcal é, de todas as formas de ocupação humana do espaço, a que representa maior esforço no sentido de permanência ou sobrevivência da família: aquela forma de ocupação de espaço cuja arquitetura, cuja escultura, cuja simbologia continua e até aperfeiçoa a das casas-grandes e dos sobrados dos vivos, requisitando-se, dentro de espaços imensamente menores, que os ocupados por essas casas senhoriais, em desafios ao tempo. (FREYRE, 2002, p. 674-675) 
O desafio ao tempo é perdido, mesmo porque não poderia ser de outro modo. $O$ tom de Freyre parece emocional, sem o distanciamento que se esperaria do sociólogo mais tradicional. Mas Freyre, embora conservador em outros sentidos, não é propriamente um sociólogo tradicional, e essa participação do sentimento do autor, que praticamente coloca a primeira pessoa no lugar da terceira, coisa que acontece sem maiores problemas em outros trechos, derrama-se no estilo do texto: a diferença é que diferentemente do que acontece mesmo em outros momentos igualmente nostálgicos e sentimentais, não é comum esse tom choro e quase ressentido na obra de Gilberto Freyre. É aqui provavelmente que se flagra o aspecto conservador de sua obra em contraponto ao aspecto progressista: pense-se de um lado na defesa que o sociólogo pernambucano fizera ao negro escravizado e aos mestiços; considere-se que a mestiçagem é fruto em boa parte da própria escravidão; seria a princípio uma boa base para a construção da sociedade (o mestiço carregaria as qualidades de todas as raças em vez de trazer sua degenerescência); a sociedade que dera origem a essa construção social através do horror da escravidão estava se acabando corroída por dentro e por fora; um sinal ao mesmo tempo indireto e claro dessa decadência é o abandono pelo qual passam tanto as antigas moradas dos vivos quanto as antigas moradas dos mortos.

Vãs pretensões. A ruína ou degradação dos sobrados, das casas nobres, das casas-grandes, dos próprios túmulos ou jazigos de família mais suntuosos, é tão frequente, no Brasil, que parece revelar, no brasileiro, singular negligência pelo que foi obra ou fundação de antepassado ou de avô morto. Não neguemos ao brasileiro esse defeito que, aos olhos dos entusiastas do Progresso com $\mathrm{P}$ maiúsculo, se apresenta, talvez, como qualidade: os mortos que não perturbem as atividades criadoras dos vivos com as sobrevivências de suas criações já arcaicas. A verdade é que, desintegrado o patriarcado, aquelas casas, aqueles sobrados, aqueles túmulos, só raramente podem ser mantidos por uma sociedade pós-patriarcal ou - diria o professor Carl C. Zimmermann - "atomística", como, em suas formas dominantes, grande parte da brasileira hoje. À decadência de famílias por três, quatro, cinco ou seis gerações patriarcalmente opulentas, teria de corresponder o que vem acontecendo entre nós: a ruína, por abandono, de velhas casasgrandes de fazenda ou de engenho; ou a sua transformação em fábricas, asilos, quartéis, refúgios de fantasmas de subúrbio ou de malandros de cais. A transformação, também, de antigos sobrados urbanos ou suburbanos, outrora habitações de famílias solidamente patriarcais, em hospitais, cortiços, "cabeças-de-porco", prostíbulos, escolas, museus, 
conventos, colégios, pensões, hotéis, fábricas, oficinas, depósitos de mercadorias, armazéns. (FREYRE, 2002, p. 675)

De que tempo propriamente fala Gilberto Freyre? Boa parte dos seus dados pode ser recomposta cronologicamente: a documentação que o sociólogo oferece é farta e generosa nesse sentido. Em compensação, esse tempo progressivo pode ser enganoso. Pois, "para Freyre, o passado nunca é totalmente esquecido, mas sim, vivo e pulsante, projetando-se no presente e no futuro. Afinal, para ele, o tempo era "tríbio", ou seja, passado, presente e futuro se interpenetravam continuamente" (OLIVEIRA, 2015, p. 450). O que é bastante sintomático para a simbologia da decadência dos antigos sobrados e mesmo para os antigos jazigos. A decadência dos elementos passados se encontra num tempo presente e faz com que se possa ler de uma maneira diversa esse mesmo presente, sobretudo quando se leva em consideração aspectos tão caros à modernidade como a falta de apreço pelas permanências. O livro perdido seria a quarta e última das dualidades expostas por Freyre, lembrando o método de composição dos títulos das três obras anteriores. Isso dá conta, por exemplo, da precedência que Freyre deu ao negro no lugar do índio, que também foi escravizado, para a construção do primeiro dos títulos, que destaca a casa-grande e a senzala, mais como complementos, aliás, do que como oposição, mas como complementos que dialogam sem evitar certo conflito. No caso, importava a Freyre as construções sociais que dariam origem primeiramente ao patriarcado latifundiário, ou seja, àquele que a partir do ciclo nordestino da cana-de-açúcar lançaria as bases da família colonial brasileira.

No livro seguinte, a dialogia se mostrará um pouco mais conflituosa, mas em termos que não aparecem diretamente denunciados pelos próprios títulos: o conflito não se dará diretamente entre o sobrado, a casa nobre que de certo modo representa a casagrande rural, e o mucambo, que é mais um contraponto do que um complemento da senzala, ainda que em certo sentido seja a sua continuação. O que acontece é que começa a se romper a contiguidade que havia entre a casa-grande e a senzala. Ainda que os poderes de mando permaneçam, e que a força representativa dos senhores ainda se mantenha, pois apesar de tudo ainda se trata de um país patriarcal na origem e na base, a urbanização já representa, por si mesma, uma separação, um 
distanciamento importante entre as duas moradias anteriores. Os poderes permanecem, mas diminuídos. A simbologia começa a ser prejudicada. O patriarcalismo rural, na cidade, começa a se mostrar uma força anacrônica e estagnante. A verdadeira luta que vai se travar aqui é com a rua, que exigirá um tipo de civilização mais avançado e mais aproximado dos modelos europeus, e fará com que surjam conflitos internos que antes não poderiam ser imaginados, dada a respeitabilidade do patriarca.

Para Freyre, herdeiro, beneficiário e defensor do tipo de sociedade que desse modo se construía, ainda não se trata de um trauma. A abertura, para Freyre democrática, que se dá com o conflito entre a rua e o sobrado é um fator importante para tornar mais maleável a rígida estrutura patriarcal que tivera início nos meios rurais do ciclo da cana-de-açúcar, que entrara em decadência desde o início da mineração. Essa democratização ou abrandamento da sociedade, democratização, diga-se mais uma vez, que se dá em termos bastante distintos daqueles que se dão no ocidente de um modo geral, têm ponto alto com a ascensão social do bacharel, típico elemento urbano e citadino, e a possibilidade de ascensão social do mulato, a qual muitas vezes vai se concretizar sob a proteção do exército, tema do livro seguinte que encerraria a trilogia.

O trauma, apenas adivinhável no tom de revolta contida do sociólogo pernambucano nos trechos que dão conta de um livro perdido, se dá ironicamente num tempo concomitante ao da Proclamação da República. O tema do livro perdido permanece no título, única coisa que sobrou da obra. Ao que tudo indica as tensões sociais muitas vezes amenizadas nas outras obras, já que um dos objetivos do autor era defender a possibilidade de uma democracia racial, apareceriam de modo mais ríspido nesse último livro, que daria conta justamente dos rituais de sepultamento, e de certo modo dos modos como os poderosos desejavam perpetuar seus nomes a partir da suntuosidade de suas últimas moradas, a qual era inacessível para os mais pobres, dentre os quais muitos seriam ainda negros e mestiços.

Jazigos e covas rasas. O título estava plenamente definido pelo autor, e o título só se define quando se sabe exatamente do que se pretende tratar. Segundo Freyre, seria um volume conclusivo e estenderia toda a discussão sobre os antagonismos sociais a partir das diferenças dos 
tipos de habitação na última morada. Mas não apenas isso. Freyre pretendia analisar o desenvolvimento e a desintegração da sociedade brasileira (especialmente da família patriarcal), por meio do estudo dos ritos de sepultamento e talvez das diferenças entre os ritos das camadas mais ricas e das camadas mais pobres da sociedade, levando em consideração também a influência de mortos sobre vivos ou a maneira como os modos e costumes, as verdades e as regras de quem já partiu podem interferir na vida de seus familiares por mais de uma geração. Para isso, enfatiza inicialmente as disparidades entre o túmulo monumental, ou o jazigo denominado perpétuo, e a cova rasa, marcada com uma cruz de madeira. (ARAGÃO, 2011, p. 93)

A dialogia entre as habitações para os pobres e para os ricos colocada no título de Sobrados e mucambos encontraria, nessa última obra, um contraponto ainda mais brutal e chocante. A miséria final simbolizada pela própria morte, da qual não pode escapar nem o rico nem o pobre, parece disfarçada, e ao mesmo tempo adiada, para uns e tornada ainda mais clara e inescapável para outro: o rico disfarça a destruição da morte com a construção de jazigos capazes de sobreviver a várias gerações, pelo menos em intenção. Para os pobres, o desaparecimento já parece indicado pela miséria das covas rasas.

Mas a manutenção desse privilégio final por parte dos antigos senhores patriarcais dependia de uma coisa que não poderia ser sustentada, a manutenção do seu próprio mundo. Com o seu desaparecimento gradual, tanto as casas dos vivos quanto as casas dos mortos, desses que antes se protegiam da rua e depois pareciam se proteger da indignidade da morte, aparecem agora na sua miséria de abandono. Ao contrário da casa do pobre e da cova rasa do pobre, naturalmente, será um processo mais lento, degradando construções a princípio mais sólidas, mas ainda assim se concretizando num processo inevitável.

Não se sabe, afinal, o que teria realmente acontecido com o livro perdido de Gilberto Freyre, embora tudo leve a crer não só que tenha sido mais que esboçado, como que estaria próximo de uma versão final, e depois acabou infelizmente perdido. Sua ausência, porém, tornou de certo modo o livro sintomático do seu próprio assunto. Um livro que falava sobre a decadência e o gradual desaparecimento de toda uma civilização acabou ele mesmo perdido. Num caso e no outro, o peso da ausência se sente como uma sombra. O Brasil não é mais patriarcal como nos tempos de que fala 
Freyre, mas aspectos desse patriarcalismo continuam presentes, de um modo que talvez não se possa ver com o otimismo de Freyre, e ainda em conflito com uma maior abertura da sociedade. Num e noutro caso, o passado e o presente se projetando no futuro, tratam-se de ausências fundantes.

\section{CONSIDERAÇÕES FINAIS}

A revolucionária obra de Gilberto Freyre deve ser vista num balanço geral que permita que se veja a profunda ruptura que o sociólogo pernambucano operou no que diz respeito à tradição anterior, predominantemente eugênica, que via no negro um elemento inferior que prejudicava na construção da sociedade brasileira e na construção do brasileiro em si. É certo que, com o tempo, outras contradições foram surgindo dentro da obra, a mais polêmica das quais seria a defesa de uma democracia racial que compensaria ou pelo menos justificaria o brutal processo de colonização pelo qual passou o Brasil. Perceba-se que não poderia ser de outro modo para um autor saudosista como Freyre: o sociólogo, que se considerava conservador, apesar das rupturas intelectuais provocadas por sua obra, desejava a conservação e a preservação de um tipo de sociedade especificamente brasileira, que se baseara com a construção do patriarcalismo latifundiário e com o seu abrandamento, como o advento da urbanização, a qual teria como consequência mais ou menos direta a ascensão social do mulato e do bacharel, em casos específicos na mesma pessoa, tendo ápice com a proclamação da República e a entrada na sociedade de negros e mestiços, pelo exército, segundo o sociólogo, ter-se mostrado uma instituição racialmente menos restrita. A defesa desse modo de vida ou o lamento por seu desaparecimento ao que tudo indica estavam bem condensados num livro já pelo título bastante simbólico: Jazigos e covas rasas, que daria conta dos rituais de sepultamento dos ricos e dos pobres. O livro se perdeu e seu eco se encontra apenas nos prefácios e introduções a Sobrados e mucambos e Ordem e progresso. Mas esses ecos, e mesmo essa perda, ainda dão conta da nostalgia traída do autor. Para o bem ou para o mal, e as contradições de Gilberto Freyre dão conta disso, o patriarcalismo que lhe deu origem, está é franca decadência e acelerado desaparecimento.

\section{REFEÊNCIAS BIBLIOGRÁFICAS}


ADORNO, T. W. Notas de literatura I. Trad. Jorge de Almeida. São Paulo: Duas Cidade/Editora 34, 2008.

ARAGÃO, Solange de. "Jazigos e covas rasas: o livro que Gilberto Freyre não escreveu?" In: Oculum Ensaios, n. 13. Campinas. pp. 88-96. Janeiro-junho, 2011.

FREYRE, Gilberto. Casa-grande \& senzala - Formação da família brasileira sob o regime da economia patriarcal.Sobrados e mucambos - decadência do patriarcado rural e desenvolvimento urbano. In: Intérpretes do Brasil. Vol. II. Rio de Janeiro: Nova Aguilar, 2002. pp. 121-646/647-1379.

LOPES, Moisés Alessandro de Souza. "A 'intoxicação sexual' do novo mundo: sexualidade e permissividade no livro Casa-grande \& senzala." In: Revista Mediações, Londrina, v.8, n.2, jul./dez.2003. pp. 171-189. MARTINS, Wilson. Literatura brasileira. São Paulo: Cultrix, 1973.

MELO, Alfredo César. Saudosismo e crítica social em Casa grande \& senzala: a articulação de uma política da memória e de uma utopia. Estudos avançados, 23 (67), 2009. pp. 279-296.

OLIVEIRA, Amurabi. "Do pretexto ao subtexto de Casa-grande \& senzala." Anos 90, Porto Alegre, v. 22, n. 42, p. 449-457, dez. 2015.

RIBEIRO, Renê Salmito. Menino de engenho, Doidinho e Bangüê: aspectos da trilogia de formação de José Lins do Rego. Dissertação de Mestrado apresentada ao Programa de Pós-Graduação em Ciência da Educação da Universidad Del Sol para obtenção do Título de Mestre em Ciências da Educação. Assunción, 2018.

SCHNEIDER, Alberto Luiz. "Iberismo e luso-tropicalismo na obra de Gilberto Freyre." In: História da historiografia. Ouro Preto. n. 10, dezembro de 2012, pp. 75-93.

SCHWARZ, Roberto. Duas meninas. 2ª ed. São Paulo: Companhia das Letras, 2006.

Enviado: Agosto, 2020. 
Aprovado: Novembro, 2020. 